\title{
Impact of Front Line Demonstration on the Yield and Economics of Fenugreek in Southern Rajasthan
}

\author{
Abhay Dashora $^{{ }^{*}}$, R. L. Solanki ${ }^{2}$, Urmila ${ }^{1}$, B. G. Chhipa ${ }^{1}$ and Pratap Bhan Singh ${ }^{1}$ \\ ${ }^{1}$ Rajasthan College of Agriculture, ${ }^{2}$ Krishi Vigyan Kendra Maharana Pratap \\ University of Agriculture and Technology, Udaipur, Rajasthan, India \\ *Corresponding author
}

\section{Keywords}

Fenugreek, front line demonstrations, gap analysis, economics and yield

\section{Article Info}

Accepted:

18 May 2020

Available Online:

10 June 2020

\section{A B S T R A C T}

Front line demonstrations on yield enhancement of fenugreek variety $\mathrm{AFg}-3$ were conducted at different villages of Chittorgarh and Udaipur districts during 2018-19. A total of 60 front line demonstrations were conducted on fenugreek in 12 ha by the active participation of the farmers with the objective of improved technologies of fenugreek production potentials. In the demonstration fields, seed of improved variety (AFg-3)along with all improved packages of practices of fenugreek were applied.The demonstrated plot recorded an average yield ranging from $1514-1763 \mathrm{~kg} / \mathrm{ha}$ in the reported villages of Chittorgarh and Udaipur districts. The yield appreciation of 19.20 $\%$ and $22.89 \%$ were recorded in demonstration fields of Chittorgarh and Udaipur districts, respectively due to technical intervention.The average extension gap, technology gap and technology index were $286 \mathrm{~kg} / \mathrm{ha}, 1062 \mathrm{~kg} / \mathrm{ha}$ and $39.32 \%$, respectively over the locations. Front line demonstrations recorded higher net returns of Rs. $50204 \mathrm{~kg} / \mathrm{ha}$ and $40008 \mathrm{~kg} / \mathrm{ha}$ with 1.72 and 1.42 benefit: cost (B:C) ratio in the respective locations by adopting packages of practices. Present results clearly indicate that the yield and economics of fenugreek can be boost up by adoption of recommended technology which in turn will improve socio-economic status of fenugreek farmers of southern Rajasthan.

\section{Introduction}

India is known as the "Land of Spices." It is the largest producer, consumer as well as exporter of spices and spice products in the world. Rajasthan and Gujarat are known as 'Seed Spices Bowl' and contributes more than $80 \%$ of total seed spices production in India.Out of the total 63 spices grown in India, 20 are being classified as seed spices. Among them, cumin, coriander, fennel and fenugreek are considered as major seed spices. Fenugreek (Trigonellafoenumgraecum L.), belongs to the family Fabaceae, is one of the important seed spices of Rajasthan.

More than 80 per cent area and production of India is contributed by Rajasthan state alone and it is mainly cultivated in the districts of Bikaner, Jodhpur, Churu, Sikar, Pratapgarh, Jhunjhunu, Nagore, Chittorgarh and Jhalawar. 
Fenugreek is used both as a food and food additive as well as in medicines. Fresh tender pods, leaves and shoots are eaten as curried vegetable. Powder of dried leaves is also used for garnishing and flavoring variety of food. It is one of the principle constituent of curry powder. The seeds of fenugreek are good source of diosgenin. The fenugreek can be cultivated in all types of soils but well drained sandy loam and medium loam soils are suitable for the crop.

Although, fenugreek is cultivated as major seed spice in Rajasthan, but the productivity is still low primarily due to non-availability of suitable variety(s) in time as well as lack of improved production technologies, more specifically the method of sowing and nutrient management. The productivity of fenugreek could be increased by adopting recommended scientific and sustainable management production practices. The farmers of Chittorgarh and Vallabhnagar districts are growing fenugreek since long back using local or low yielding varieties without adopting standard package of practices. Farmers of some pockets are still following practice of broadcasting for sowing which poses hurdle in intercultural operations during crop growth period. It reduces both quality and yield of fenugreek. Therefore, front line demonstration programme was an effective tool for increasing the productivity of crop and changing knowledge, attitude and skill of farmers. The main objective of Front Line Demonstrations is to demonstrate newly released crop variety, production and protection technologies and it's management practices in the farmer's field under different agro-climatic regions and farming situations. Research Scientists/SMS from ARS as well as KVks are organizing regularly on-campus and off-campus training programmes for the benefits of farmers and farm women in order to make them aware about new crop technologies.
In order to evaluate the impact of these trainings, the present study was undertaken with the objectives to assess the knowledge and adoption level of package of practices under FLD on the farmers field of Chittorgarh and Udaipur districts and to find out the yield gap in fenugreek production.

\section{Materials and Methods}

The present study was carried out by the ARS, Udaipur and KVKs of MPUAT, Udaipur during 2018-19. A total of 60 demonstrations of 12 hectares were conducted on the farmer's field of Chittorgarh and Udaipur districts using new fenugreek variety Ajmer Fenugreek-3 (AFg-3) in order to popularize this variety as well as scientific production technologies among the farmers. Out of 60 demonstrations, 40 were conducted on the farmers field of villages Sukhwada, Kannoj, Haziakheri, Thukrawa and Ganpatkheda, Tehsil-Bhadesar, Chittorgarh district and 20 were conducted on farmers field of villages Khedi and Falichda, TehsilMavli of Udaipur district. All the selected farmers were successfully trained by scientist before sowing with the knowledge of latest production technology. The demonstrated plot of each beneficiary is 0.20 ha.

All the required input viz., Seed, fertilizers, plant protection chemicals were distributed to the farmers for demonstrations. The data were collected through personal contacts with the help of well-structured interview schedule. The yield and economic performance of frontline demonstrations, the data on output were collected from FLDs as well as local plots and finally the grain yield, cost of cultivation, net returns with the benefit cost ratio was worked out. The generated data were utilized for calculating the technology gap, extension gap and technology index using the formula as suggested by Samui et al., (2000). 
Extension gap (qha-1) = Improved yield (Demonstration)- Farmer's yield

Technology gap (qha-1) = Potential yieldImproved yield (Demonstration)

Technology index $(\%)=[$ Technology gap $/$ Potential yield] x 100

\section{Results and Discussion}

Results of 60 front line demonstrations, which were conducted at Chittorgarh district and at Vallabhnagar Tehsil in Udaipur district of Southern Rajasthan during 2018-19 on 12 hectares areas. The data on yield and yield enhancement over local checks and other correlated factors are presented in Table 2-4. The differences in adoption of front line demonstrations (improved practices) and local farmers practices (local check) of fenugreek production technologies were measured as per recommended package of practices in which the major differences was observed regarding high yield variety (HYVs), seed rate, seed treatment, balance use of fertilizers, weed management and plant protection measures.

The details of package of practices adopted under demonstration and farmers practices are given in Table 1. These differences in the packages of practices were in line with the findings of G. Lal, et al., 2017, Choudhary and Kantwa, 2014, Singh and Varshney, 2010 and Veerasamy, et al., 2003. A comparison of the productivity level between front line demonstrations and local checks is shown in Table 2. It is evident from results that under the demonstrate plot, yield performance of fenugreek was sustainable higher than that in the local check in both of districts i.e. Chittorgarh and Udaipur. Yield in fenugreek under demonstration ranged from 1514 -1763 $\mathrm{kg} / \mathrm{ha}$ in the reported villages of Chittorgarh and Udaipur districts. Technological intervention, thus, enhanced yield to a tune of
$21.05 \%$ over the local check. However, variation in yield observed over the locations were mainly on account of varying climatic condition and in agricultural practices adopted. The results indicated that the FLDs have given a good impact over the farming community of seed spices and motivated them for adopting new agricultural technologies. These effects in the demonstration packages were in line with the findings of G. Lal, et al., 2017, Poonia, et al., (2017) and Verma, et al., 2016

Yield in front line demonstration and potential yield of the crop was compared for estimating yield gaps. These gaps were further categorized as technology and extension gaps. Technology gap indicates a gap in demonstration yield over the potential yield, and this was 937 and $1186 \mathrm{~kg} / \mathrm{ha}$ at the villages of Chittorgarh and Udaipur districts, respectively (Table 3 ).

The technology gap observed may be attributed to dissimilarities in climatic conditions including soil fertility, salinity and other vagaries of weather in the demonstration areas. Hence, to narrow down the gap between the two types of yield in different varieties, location specific recommendation may become necessary. Extension gap of $328 \mathrm{~kg} / \mathrm{ha}$ was observed in Chittorgarh district while in Udaipur district it was $244 \mathrm{~kg} / \mathrm{ha}$.

A wide extension gap emphasizes the need to educate farmers using various means to facilitate adoption of improved production technologies, to reverse this trend. More use of latest and improved production technologies applied to high yielding varieties can subsequently bridge this extension gap between demonstration yield and farmer's yield. New technologies, may, eventually lead farmers into discontinuing old or poor yielding varieties. 
Table.1 Difference between demonstration package \& farmers practices of fenugreek in Chittorgarh and Udaipur districts during 2018-19

\begin{tabular}{|c|c|c|}
\hline Particular practice & Demonstration package & Farmers practices \\
\hline Variety & AFg. 3 & Local \\
\hline Seed rate & $20 \mathrm{~kg} / \mathrm{ha}$ & $25-30 \mathrm{~kg} / \mathrm{ha}$ \\
\hline Seed treatment & Carbendazim @2 g/kg seed & Not applied \\
\hline Sowing method & Line sowing & Broadcasting \\
\hline Weed control & $\begin{array}{l}\text { Oxidiazaryl @ } 75 \mathrm{~g} / \mathrm{ha} \text { just after sowing } \\
\text { and before germination followed by one } \\
\text { hand weeding at } 45 \text { days after sowing }\end{array}$ & Hand weeding \\
\hline Fertilizer Doses & 25: 40 (N: P kg/ha) & $\begin{array}{l}\text { Less or more quantity } \\
\text { without knowledge }\end{array}$ \\
\hline $\begin{array}{l}\text { Plant protection } \\
\text { measures }\end{array}$ & $\begin{array}{l}\text { Need based spray of insecticide \& } \\
\text { fungicides }\end{array}$ & $\begin{array}{l}\text { No use of insecticides \& } \\
\text { pesticides }\end{array}$ \\
\hline
\end{tabular}

Table.2 Yield and yield difference of fenugreek under Front Line Demonstrations during 2018-19

\begin{tabular}{|l|c|c|c|c|c|}
\hline \multicolumn{1}{|c|}{ District } & $\begin{array}{c}\text { No. of } \\
\text { FLDs }\end{array}$ & \multicolumn{2}{|c|}{ Avg.Yield (kg/ha) } & $\begin{array}{c}\text { Additional yield } \\
\text { over local check } \\
\text { (kg/ha) }\end{array}$ & $\begin{array}{c}\text { Per cent increase } \\
\text { yield over local } \\
\text { check }\end{array}$ \\
\hline Chittorgarh & 40 & 1763 & 1435 & 328 & 22.89 \\
\hline Udaipur & 20 & 1514 & 1270 & 244 & 19.20 \\
\hline Mean & & $\mathbf{1 6 3 9}$ & $\mathbf{1 3 5 3}$ & $\mathbf{2 8 6}$ & $\mathbf{2 1 . 0 5}$ \\
\hline
\end{tabular}

Table.3 Yield and gap analysis of fenugreek in the districts of Chittorgarh and Udaipur under front line demonstrations during 2018-19

\begin{tabular}{|c|c|c|c|c|c|}
\hline District & $\begin{array}{c}\text { Potential yield } \\
\text { of AFg-3(kg/ha) }\end{array}$ & $\begin{array}{c}\text { No. of } \\
\text { FLD }\end{array}$ & $\begin{array}{c}\text { Technology } \\
\text { gap(kg/ha) }\end{array}$ & $\begin{array}{c}\text { Extension } \\
\text { gap (kg/ha) }\end{array}$ & $\begin{array}{c}\text { Technology } \\
\text { Index (\%) }\end{array}$ \\
\hline Chittorgarh & 2700 & 40 & 937 & 328 & 34.70 \\
\hline Udaipur & 2700 & 20 & 1186 & 244 & 43.93 \\
\hline Mean & & & 1062 & $\mathbf{2 8 6}$ & $\mathbf{3 9 . 3 2}$ \\
\hline
\end{tabular}

Table.4 Economics of Frontline Demonstrations on fenugreek at Chittorgarh And Udaipur districts

\begin{tabular}{|l|c|c|c|c|c|c|c|c|}
\hline \multirow{2}{*}{ Location } & \multicolumn{2}{|c|}{$\begin{array}{c}\text { Cost of Cultivation } \\
\text { (Rs/ha) }\end{array}$} & \multicolumn{2}{c|}{$\begin{array}{c}\text { Gross return } \\
\text { (Rs/ha) }\end{array}$} & \multicolumn{2}{|c|}{$\begin{array}{c}\text { Net return } \\
\text { (Rs/ha) }\end{array}$} & \multicolumn{2}{|c|}{ B:C ratio } \\
\cline { 2 - 10 } & FLD & $\begin{array}{c}\text { Local } \\
\text { Check }\end{array}$ & FLD & Local & FLD & Local & FLD & Local \\
Check & & Check & & Check \\
\hline Chittorgarh & 29110 & 26500 & 79314 & 64553 & 50204 & 38053 & 1.72 & 1.44 \\
\hline Udaipur & 28100 & 25370 & 68108 & 57139 & 40008 & 31769 & 1.42 & 1.25 \\
\hline Mean & $\mathbf{2 8 6 0 5}$ & $\mathbf{2 5 9 3 5}$ & $\mathbf{7 3 7 1 1}$ & $\mathbf{6 0 8 4 6}$ & $\mathbf{4 5 1 0 6}$ & $\mathbf{3 4 9 1 1}$ & $\mathbf{1 . 5 7}$ & $\mathbf{1 . 3 5}$ \\
\hline
\end{tabular}


Technology index refer to the feasibility of variety at farmers field. A lower the value of technology index, more is the feasibility (Table 3). This finding corroborates results of G. Lal, et al., 2017 and Poonia, et al., 2017.

The economics of growing fenugreek under front line demonstrations were estimated and results are presented in Table 4. Economic analysis of yield performance revealed that besides higher production, participating farmers in FLDs realized a higher price of than produce compared to that in the local checks during the period under study. This was so because of a better quality of the produce. Front line demonstrations recorded higher mean gross return(Rs.73711/ha) and mean net returns (Rs.45106/ha) with average benefit: cost ratio (1:57) compared to the local check. These results are in line with finding of G. Lal, et al., 2017, Poonia, et al., 2017 and Singh et al., 2011.

On the basis of above findings in the present study, it is concluded that front line demonstrations of improved technology reduce technology gap to a considerable extent, thus leading to increased productivity of fenugreek in Chittorgarh and Udaipur district of Rajasthan.

The productivity of fenugreek under FLDs over traditional practice of fenugreek cultivation created greater awareness among farmers and also motivated the other farmers to adopt such appropriate production technology for getting higher yield in the Chittrorgarh and Udaipur district of Rajasthan. The selection of specific technology like improved varieties, seed rate, seed treatment, seed inoculation, balanced use of fertilizer and plant protection measures were undertaken in a proper way.This also improved linkages between farmers and scientists, and built confidence for adoption of the improved technology.
It is an effective tool for increasing the productivity of crops and changing knowledge, attitude and skill of farmers.

\section{Acknowledgement}

The Authors are thankful to the Director, Directorate of Arecanut and Spices Development, Ministry of Agriculture \& Farmers Welfare, Department of Agriculture, Co-operation \& Farmers Welfare, Calicut, Kerala for financial support for FLDs programme along with the Director Research, DORand Director, Extension Education, DEE, MPUAT, Udaipur for providing facility for the same.

\section{References}

Choudhary, M. L. and Kantwa, S. L. 2014. Assessment of front line demonstration on yield enhancement of cumin (GC-4) in Barmer district of Rajasthan. Annals of Horticulture. 7 (1): 6-9.

Lal, G., R. S. Mehta, R. S. Meena, N. K. Meena and M. L. Choudhary. 2017.Assessment of front line demonstrations on yield enhancement of fenugreek under TSP area in pratapgarh district of Rajasthan. International J. Seed Spices 7(1):60-64

Poonia, M.K., Mahendra Singh, B.L. Dhaka, R.K. Bairwa and Bheru Lal Kumhar. 2017. Impact of Front Line Demonstration on the Yield and Economics of Coriander in Kota District of Rajasthan, India. Int.J.Curr.Microbiol.App.Sci. $\quad$ 6(3): 2344-2348.

Samui, S.K., Maitra, S., Roy, D.K., Mondal, A.K. and Saha, D. 2000. Evaluation of front line demonstration on groundnut (Arachis hypogea L.) in Sundarbans. J. of Indian Society of Coastal Agri. Re., 18(2): 180-183.

Singh, D. Meena, M. L. and Choudhary, M. 
K. 2011. Boosting seed spices production technology through front line demonstrations. International $J$. Seed Spices. 1 (1): 81-84.

Singh, P. K. and Varshney, J. G. 2010. Adoption level and constraints in coriander production technology. Indian Research J. Extension Education. 10 (1): 91-94.

Veerasamy, S., Satpathy, C. and Rao, G. A.
2003. Constraints of coriander production in Orissa. Indian Research J. Extension Education. 33 ( 1 \& 2): 5863

Verma, Arjun Kumar, Singh, Mahendra, Singh, Navab, Jeenger, K.L. and Verma, J.R. 2016. Dissemination of improved practices of coriander through FLDS in Zone V of Rajasthan province. Int. J. Sci. Envion. Tech., 5(5): 3320-27.

\section{How to cite this article:}

Abhay Dashora, R. L. Solanki, Urmila, B. G. Chhipa and Pratap Bhan Singh. 2020. Impact of Front Line Demonstration on the Yield and Economics of Fenugreek in Southern Rajasthan. Int.J.Curr.Microbiol.App.Sci. 9(06): 1397-1402. doi: https://doi.org/10.20546/ijcmas.2020.906.174 